\title{
OSMANLI PEDAGOGLARINDA DİSİPLIN, ÖDÜL VE CEZA FİKİRLERİNE DAİR ÖRNEKLER
}

\author{
Hamza ALTIN*
}

\author{
$\ddot{O} \mathbf{z}$
}

$\mathrm{Bu}$ çalışmada, Osmanlı pedagoglarının disiplin, ödül ve cezaya dair fikirleri incelenmektedir. Osmanlı dönemi pedagogları, yazdıkları pedagoji eserlerinde ve makalelerinde konuya çeşitli açılardan yaklaştılar. Eğitim hayatında okulda disiplini sağlama adına ceza ve ödüle yer verilmesi gerektiğini savundular.

Eğitimde dayak ve şiddete kesinlikle karşı çıkan Abdullah Vehbi Bey, eğitimde ceza ve şiddet yerine tembih ve güzel muamelenin tercih edilmesi taraftarıydı. Zira ona göre öğrencilere ikincisi ile yaklaşmak her zaman daha çabuk sonuca götürebilirdi.

Musa Kazım Bey’in eğitimde önem verdiği, öğretmenlerin bilmelerini gerekli gördüğü konulardan biri de "Mükâfat ve Mücazat" (Ödül ve ceza) meselesidir. Memlekette adil ve kadirşinas insanların çoğalmasını sağlamak için öğretmenler eğitim hayatında bu iki konuya önem vermelidirler. Öğretmen dersine çalışan, okulun kurallarına uyan öğrencileri taltif etmeli, bunun aksi yönde hareket eden öğrencileri de cezalandırmalıdır.

Süleyman Paşazade Sami Bey’in düşüncesine göre; öğrencilerin her biri doğal olarak öğretmen tarafından sevilmek, takdir edilmek ve mükâfatlandırılmak isterler. Öğretmen ders çalışana, hâl ve hareketlerine dikkat eden öğrencilere iltifat ederse diğer öğrenciler arasında da bu iltifatlara layık olmak isteyenler olacaktır. Yalnız öğretmenin bu konuda dikkat etmesi gereken şey, sadece başarılı öğrencileri değil bunun için çaba harcayan bütün öğrencileri taltif etmesidir.

Sabri Cemil'in fikrince hakiki disiplin, disipline aykırı bir olay olmadan alınan tedbirlerle onu keşfetmek ve olay cereyan etmeden ortadan kaldırmaktır. Öğretmenlerin nüfuzunu kullandığı iyi bir okulda cezaya müracaat etmeye gerek kalmaz.

Anahtar Sözcükler: Eğitim, öğrenci, disiplin, ödül, ceza.

\section{EXAMPLES FOR THE THOUGHTS ON DISCIPLINE, REWARDS AND PUNISHMENTS OF THE OTTOMAN PEDAGOGS}

\begin{abstract}
In this present study, the thoughts on discipline, reward and punishment of Ottoman pedagog are examined. Ottoman pedagogs, in their works on pedagogy considered the problem in various perspectives. They defended the use of reward and punishment in education for keeping the discipline.

Abdullah Vehbi who strictly opposed to beating and punishment in education, instead defended monition and compliments. Likewise, according to him reaching the students with the second method will always lead to result quicker.
\end{abstract}

\footnotetext{
* Doç. Dr.; Kilis 7 Aralık Üniversitesi Fen Edebiyat Fakültesi Tarih Bölümü, hamzaaltin23@gmail.com.
} 
One of the issues that were Musa Kazim placed importance is also the reward and punishment. According to him, for increasing just and grateful people in the country, teachers must attach importance to these two issues. The teacher should reward the students who study their lessons and obey the rules of the school and punish those who act in opposite.

Süleyman Paşazade Sami thought that each student naturally wants to be loved, appreciated and rewarded by the teacher. If the teacher compliments the students who study their lessons and be in good manners, the other students will also want to deserve these compliments. However, the teacher should be careful on not only reward the students who are good in lessons but also he should reward those who also work hard to achieve success.

According to Sabri Cemil, real discipline is to take precautions before an action that is against the discipline and prevent it to happen. For a good school which teachers use their influence, there will be no need for use of punishment.

Keywords: Education, student, discipline, reward, punishment.

\section{Giriş}

Ödül (mükâfat) ve ceza (mücazat) ile ilgili olarak birçok Osmanlı eğitimcisi fikir beyan etmiştir. Eserlerinde söz konusu konuya değinmişlerdir. Kendi aralarında yaptıkları tartışma konularından biri de ödül ve ceza kavramlarıdır (Kafadar, 1997, s. 99; Kardaş, 1978, s. 194). Misal Ziya Gökalp ve Satı Bey'in muallim mecmuasındaki ünlü polemiklerinde bu kavramlara da değinilmekteydi (Berkes, 2002, s. 455).

$\mathrm{Bu}$ çalışmada, Osmanlı pedagoglarının disiplin, ödül ve cezaya dair fikirleri incelenecektir. Fakat söz konusu kavramlar ile ilgili Osmanlı eğitim kurumlarının uygulamalarına da göz atmak faydalı olacaktır. Örneğin; Dârülmuallimât yani Kız Öğretmen Okullarında mükâfat ile ilgili şu şekilde bir uygulama söz konusu idi:

Her perşembe günü akşamı müdür yahut onun emriyle müdîre dershaneleri dolaşarak bir hafta zarfında mükâfata nail olan öğrencilerin isimlerini yüksek sesle okuyarak takdiriye belgelerini vermekteydi. Bu arada ceza alan öğrencilerin isimleri de okunmaktaydı (Altın, 2009, s. 134).

Ödül, sebebinin derecesine göre beş türlüydü. Bunlar şöyle sıralanmaktaydı:
1. Aferin
2. Tahsin
3. İmtiyaz

4. Levha-i iftihar

5. Mükâfat (Salname-i Maarif-i Umumîye,1317, s. 331) 
Aferin: Bu belge dersine çalışan, görevlerini yapan, okul kurallarına riayet eden, hâl ve hareketlerine dikkat edenlere verilmekteydi. Muavine yahut öğretmenler aferin alacak olan öğrencinin isimlerini ve aferin verilme sebebini yazmaktaydılar.

Tahsin: Dört aferine bedel olan bu belge dersine olağanüstü çalışanlara, kitap ve defterlerini temiz tutanlara, bütün görevlerini yapanlara verilmekte olan bir belgeydi. Bu belge, müdürün onayı ile muavine, öğretmenler veya mubassıra tarafından sınıf defterine yazilmaktayd1.

İmtiyaz: Sekiz aferin veya iki tahsine bedeldi. Öğretmenler, muavine ve mubassıranın çok memnun olduğu öğrencilere verilirdi. Bu belgeyi ancak müdür verirdi.

Bir öğrenciye verilen aferin belgesinin adedi on beşi, tahsinin adedi ikiyi, imtiyaz adedi biri geçemezdi. Deftere yazılan belgeler muhakkak verilmeliydi.

Levha-i iftihar: Camlı ve süslü olan bu levhaya, bir ay zarfında on beş aferin, iki tahsin ve bir imtiyaz belgesi alan öğrencilerin isimleri celi hat ile yazılıp okulun en fazla göze çarpan bir yerine asılırdı.

Mükâfat: Bir sene boyunca iki defa levha-i iftihara isimleri yazılanlara ve yıl boyunca elli aferin toplayarak müdüriyete getirenlere maddi ve manevi değeri yüksek bir kitap hediye edilirdi (Altın, 2009, s. 135).

Ödül bazen Maarif Nezaretinin yüksek bürokratları veya eşlerinin katılımı ile gerçekleşmekteydi. 5 Kasım 1883 yılında yapılan ödül töreninde yöneticilerle birlikte dönemin Maarif Nazırı Mustafa Paşa'nın hanımı da bulunmuş ve bir konuşma yapmıştı (Cevad, 2002, s. 201).

Dârülmuallimât’ta ceza konusunda ise şu şekilde bir uygulama vardı:

Ceza işlenen suça göre, yediye ayrılmaktaydı (Salname-i Maarif-i Umumîye,1317, s. 327). Bunlar şöyle siralanıyordu:

1. İhtar ve tembih.

2. Tekdir.

3. Tevkif.

4. Alenen tekdir.

5. İhbar ve şikâyet.

6. Geçici ihraç.

7. Kesin ihraç. 
İhtar ve tembih: Müdür tarafından belirlenecek müdîre, muavine veya muallime tarafından öğrenciye yapılan nasihatten ibaret idi. Derslere gereken özeni göstermemek, görevlerini yapmamak, "Küçük yaramazlıklarda bulunmak" bu cezanın verildiği durumlardı. Bu hâllerde muavine, mubassıra veya öğretmenlerden biri sınıf listesinde ceza alan öğrencinin isminin karşısına "Falan sebepten ihtar ve tembih cezası verildi." ibaresi yazılarak imzalanmaktaydı (Altın, 2009, s. 135).

Tekdir: Müdür veya onun tensibi ile müdîre odasına çağrılan öğrenciye uyarı ve nasihatte bulunulur. Derslere çalışmamak, daha önce yapılan ihtar ve tembihe kulak asmamak, gürültü ve yaramazlık yapmak hâllerinde uygulanan ceza idi. Ceza, nedeniyle birlikte, sınıf defterine işlenerek imzalanırdı.

Tevkif: Öğrenciyi yemek teneffüsünden mahrum edip bir muavine veya mubassıranın gözetiminde, tahsis edilen bir dershanede ona yazı yazdırmaktır. Tembih ve tekdir cezalarının yetersiz görüldüğü hâllerde verilen bir ceza idi. Bu ceza da diğerleri gibi imza ve kayıt altına alınmaktaydi.

Alenen tekdir: Sicil defterine okul müdürü tarafindan, "Falan sene talebattan falan hanım şu sebepten dolayı tekdir-i aleniye müstahak görüldü." yazılarak bu ibarenin müdür yahut onun isteğiyle, müdîre tarafından dershanede öğrencilerin önünde, alenen okunmas1 şeklinde cereyan eden cezadır. Bu ceza, öğrencilerin önceki cezalara rağmen düzelmemesi ve suçlarında ısrar etmesi, arkadaşlarıyla kavga etmesi, aşırı yaramazlık yapması hâllerinde uygulanmakta olan bir ceza türü idi. Ceza, muallim, muallime, muavine veya mubassira tarafindan sınıf defterine kayıt ve imza edilirdi.

İhbar ve şikâyet: Yukarıda bahsedilen cezalardan uslanmayıp dersine çalışmayan ve kabahatlerinde 1srar eden öğrenciler için uygulanan cezadır. Bu durum, müdür tarafindan velisine yazılı veya sözlü olarak ihbar ve şikâyet olunur.

Geçici ihraç: Ceza alan öğrenciyi işlediği kabahate göre bir haftadan bir aya kadar okuldan uzaklaştırma cezasıdır. Cezayı alan öğrencinin velisine bu durum, okul idaresi tarafından yazılı olarak bildirilir.

Kesin ihraç: Öğrenciye verilen cezaların en ağırıdır. Bu ceza bütün, uyarı ve cezalara rağmen hiçbir şekilde düzelmeyen öğrenciler için uygulanır. "İhlal-i edep ve intizama cüret edenler", maarif nezaretine bildirilerek okuldan uzaklaştırılırlar, nezaretten aksi yönde bir emir gelmedikçe de okula alınmazlar. 
Geçici ve kesin ihraçta işlenen kabahat, sınıf defterine yazılmamayı gerektirecek kadar ağır ise müdüriyete bu durumu bildirir bir rapor yazılır. Sınıf defterine ise "Falan hakkında müdüriyete ayrıca bir rapor takdim kılınmıştır." ibaresi yazılmaktaydı.

Geçici ve kesin ihraç dışındaki cezaların “Kabil-i af” olanlarını öğrencilerin telafi etme şansları vardı. Bunun için de çeşitli sayıda aferin veya tahsin almalıydılar. Cezaların affı için öğrencilerin alması gereken "Evrak-ı takdiriyeler" şunlardı:

- İhtar ve tembih: Bir aferin.

- Tekdir: İki aferin.

- Tevkif: Bir tahsin veya dört aferin.

- Alenen tekdir: Bir tahsin ve bir aferin veya beş aferin.

- İhbar ve şikâyet: Bir imtiyaz, iki tahsin veya sekiz aferin.

Bir haftalık ders sürecinde sekiz defa ihtar ve tembih veya dört tekdir veya iki tevkif veya iki tekdir-i aleni, cezasına çarptırılan öğrenci peder veya velisine şikâyet olunurdu. Ayrıca, bir ay süresince bir iki defa şikâyet olunan öğrenci geçici ihraç cezasına çarptırılırdı (Altın, 2009, s. 137).

\section{Pedagogların Disiplin ile İlgili Görüşleri}

Osmanlı pedagoglarının kafa yordukları kavramlardan biri de disiplindi. Eğitim-öğretim kurumlarında düzenin, intizamın korunması, rutin işlerin yürütülmesi için disiplinin her hâlükârda sağlanması gerekmekteydi. Bu konuda Halide Edip, Talim ve Terbiye isimli eserde, intizam ahlakının bozulmaması ve disiplinin sağlanması için ceza ve ödülü bir araç olarak görmekteydi. Talebelerin iyi davranışın karşılığında ödül, kötü davranışın karşılığında ceza görmelerini istemekteydi. Aksi takdirde disiplin konusunda zafiyet oluşacağını ileri sürmekteydi (Edip, 1327, s. 180).

Trabzon'da yayınlanan, Usûl-i İbtidâ̂ Yahut Muallimlere Rehnüma isimli eserin müellifi Abdullah Vehbi Bey’e göre, muallim ders ve teneffüs zamanlarının çizelgelerini yapmalı ve bu çizelgeye sadık kalmalıdır. Aksi takdirde disiplini sağlamak güçleşir. Ayrıca kendi özel işleri için ders saatlerini değiştirmemeli ve teneffüs sürelerini uzatıp kısaltma yoluna gitmemelidir (Vehbi, 1315, s. 7). Eğer böyle bir durum vaki olursa öğrenciler düzensizliğe ve başıboşluğa alışabilirler (Vehbi, 1315, s. 8). Disiplin ile ilgili diğer bir sorun yaş meselesidir. Ona göre eğitim-öğretimin düzeni açısından, İlkokula başlayan öğrencilerinin 
yaşları aynı olmalıdır. Bu anlamda, okula yeni başlayanlar için en uygun yaş 7 olmalıdır (Vehbi, 1315, s. 5).

II. Abdülhamid devri pedagoglarından Melekzade Fuad bazı eğitimcilerin yeteri kadar idealist davranmamasının disiplini zedelediğini ileri sürmekteydi. Ona göre muallimin işi sadece ders anlatmak değildir. Öğretmen öğrenciyi izlemeli ve her şeyiyle ilgilenmelidir. Böyle davrandığı takdirde disiplini sağlamak kolaylaşır (Melekzade Fuad, 1315, s. 61).

Osmanlı'da modern eğitim denince akla ilk gelen isimlerden olan Mustafa Satı Bey disiplin konusunda fiziki şartları da önemsemekteydi. Örneğin; talebe rahleleri birer kişilik olmalıydı. Birden fazla talebenin bir rahlede oturması sınıfta disiplinsizliğe neden olabileceği gibi, bulaşıcı hastalıkların yayılmasına da sebebiyet verebilirdi. Bu nedenle ABD okullarında bir kişilik rahleler kullanılmaktadır (Satı, 1325, s. 67). Mustafa Satı Bey’e göre öğretmenin sesi, hâl ve hareketleri hatta sınıfın düzeni öğrencinin başarı yahut başarısızlı̆̆ını etkiler. Öğretmen bunların farkına varmalı ve gerekli önlemleri almalıdır (Satı, 1325, s. 131).

Mustafa Satı Bey'in fikrine göre disiplin, başarı veya başarısızlık en nihayetinde bir vicdan meselesidir ve eğitimci bunun farkında olmalıdır. Ona göre vicdan ahlak kanunlarının en önemli yaptırım güçlerindendir. İnsan kimsenin görmediği ve herhangi bir cezaya çarptırılmayacağını bildiği hâlde dahi fenalık yapmasını engelleyen etken o insanın vicdanıdır (Sat1, 1325, s. 344).

Disiplini sağlama yolları üzerinde mesai harcayan pedagoglardan biri de Süleyman Paşazade Sami Bey'dir. Sami Bey, mükâfat ve mücazatı eğitimcinin talebeyi istediği yöne sevk etmede kullandığı disiplin vasıtaları olarak değerlendirmekteydi (Sami, 1328, s. 193).

Sami Bey’in fikrince öğretmen için bir okulda disiplini sağlamanın en kolay yolu, öğrencilerin güvenini kazanmaktır. Zira bir çocuk öğretmenin kendisinin iyiliğini düşündüğünden emin olursa öğretmenin hiçbir sözünden dışarı çıkmaz (Sami, 1328, s. 197).

Öğretmen, çocuklardan herhangi bir şeyi yapmalarını istediği zaman taviz vermeden çocuklara istediğini yaptırmalı, çocukların söz konusu işi niçin yapacaklarına dair soruları iş bittikten sonra yanıtlamalıdır. Günümüz pedagoji anlayışıyla pek fazla bağdaşmamasına rağmen bunun sebebini şöyle açıklamaktaydı:

"Yani bir çocuk hiçbir vakit aldiğı emre, esbabını bildiği için itaat ettiği, itaatine alet bu olduğu fikir ve zehabına düşmesin" (Sami, 1328, s. 198). 
Sami Bey'in eğitimcilere salık verdiği düzen ve disiplini sağlamada kullanabilecek diğer araçlardan biri de öğrenciler arasında rekabet ortamı oluşturulmasıydı. Öğrencilerin her biri, doğal olarak öğretmen tarafından sevilmek, takdir edilmek ve mükâfatlandırılmak ister. Öğretmen, ders çalışana, hâl ve hareketlerine dikkat eden öğrencilere iltifat ederse diğer öğrenciler arasında da bu iltifatlara layık olmak isteyenler olacaktır. Yalnız öğretmenin bu konuda dikkat etmesi gereken şey, sadece başarılı öğrencileri değil bunun için çaba harcayan bütün öğrencileri taltif etmesidir (Sami, 1328, s. 200-201).

II. Meşrutiyet devri önemli pedagoglarından olan Sabri Cemil (Altın, 2013b, s. 19-35) zaman cetvelinin bir disiplin aracı olarak kullanılabileceğini savunmaktaydı. Ona göre, öğrencilerin sıkı bir şekilde gözlemi disiplin için lüzumluydu. Sabri Cemil hakiki disiplini, kurallara aykırı bir olay olmadan alınan tedbirlerle onu keşfetmek ve olay cereyan etmeden ortadan kaldırmak olarak yorumlamaktaydı. Onun kanaatine göre öğretmenlerin nüfuzunu kullandığı iyi bir okulda disipline aykırı bir hadise olmaz ve cezaya müracaat etmeye gerek kalmazdi (Cemil, 1326, s. 124).

Sabri Cemil öğretmenlerin ders dışında da öğrenciyle ilgilenmesini, bazı zamanlar eve kadar onlara refakat etmelerini, ders dışındaki faaliyetlerini gizlice takip etmelerini istemekte ve bu faaliyetlerin okul disiplini açısından fevkalade yarar sağlayacağına inanmaktaydı (Cemil,1326, s.128).

Disiplini sağlamada öğretmenin dikkat etmesi gereken hususlardan biri de öğrenci yakınlarıyla görüşmesi olduğunu belirten Sabri Cemil, bu davranışın çok faydası olacağını ifade etmekte ve şunları dile getirmekteydi:

“Muallimler inzibat hususunda çocukların pederleri, biraderleri, dayı ve amcaları ile görüşmeksizin bir şeye muvafik olamazlar" (Cemil, 1326, s. 129).

Sabri Cemil düşüncesine göre öğrenciyi disipline etmek, daha çok ders çalışmasını sağlamanın yollarından birisi de rekabettir. Ancak bu yöntemi çok iyi ve yerinde kullanmak gerekir. Aksi takdirde birçok sorun ortaya çıkar:

1. Çocukların dikkati asıl görevlerinden mükâfata çevrilebilir.

2. Çocukların bazılarında gurur, ötekilerinde mahcubiyet hasıl olabilir.

3. Çocuklar arasında kin ve hasede sebebiyet verilebilir. 
4. Öğrenciler ömür boyu kendilerine farklı davranılmasını istemek gibi yanlış tutum içerisine girebilirler (Cemil,1326, s.113-114).

\section{Pedagogların Ödül ile İlgili Görüşleri}

Musa Kâzım Bey, II. Abdülhamid devrinde yayınladığı pedagoji kitabı Rehber-i Tedris ve Terbiye isimli eserinde ödül ve ceza konularını da tartışmaktaydı. Ona göre eğitimcilerin bilmeleri gereken en hayatî konulardan biri de "Mükâfat ve mücazat" (Ödül ve ceza) meselesidir. Memlekette adil ve kadirşinas insanların çoğalmasını sağlamak için muallimler eğitim hayatında bu iki konuya önem vermelidirler. Eğitimci dersine çalışan okulun kurallarına uyan öğrencileri taltif etmeli, bunun aksi yönde hareket eden öğrencileri de cezalandırmalıdır. Eğitimciler ödül ve cezanın tevzi ve tertibinde suistimalin ortaya çıkmaması için çok özen göstermelidir. Günlük derslerine çalışan gayret sarf edenlere evvela şifahi olarak teşekkür edilmeli, çalışmasını sürdürenlere bir aferin kâğıdı verilmelidir. Mükâfatta bundan sonraki aşamalar ise altmış aferin kâğıdı alan öğrenciye bir kitap hediyesi, başarının özel bir tezkire ile öğrenci velisine bildirme olmalıdır (Kâzım,1310, s. 20).

Sami Bey'in kanaatine göre eğitimcilerin öğrencileri eğitmek için kullandığ vasıtalardan biri de mükâfat olmalıdır. Eğitimci, çocukların çalışma derecelerine göre mükâfat vermeli, bu konuda haksızlık yapılmamasına dikkat etmelidir. Talebeleri sadece derse çalışma açısından değerlendirmemeli, ahlaklı, terbiyeli, hâl ve hareketi düzgün öğrenceleri de mükâfatlandırmalıdır (Sami, 1328, s. 202).

Süleyman Paşazade Sami Bey’e göre mükâfat ve ceza, bir eğitimcinin vazgeçmesi mümkün olmayan eğitim araçlarıdır. Esasen bir öğrencinin amacı mükâfat olmamalı ve onun için çalışmamalı, "Vazifesini ikmal etmek ve muallimini memnun etmek için çalışmalıdır". Bununla birlikte insanlar hedeflerine ulaştıklarında ödüllendirilmekten hoşlanırlar. Tabiatıyla çocuklarda böyledir. Bu durumda muallime düşen görev öğrencilerin mükâfatı asıl gaye olarak algılamalarına mani olmak ve mükâfatı sadece bir araç olarak kullanmaktır (Sami, 1328, s. 204).

Eğitimci talebeyi ödüllendirirken dengeli davranmalı, ödül öğrenciyi hodbin edecek derecede kıymetli olmamalı ve ödül ile ödüle layık görülen davranış mümkün mertebe mütenasip olmalıdır. Akıl, zekâ veya ahlaka ait ödüllendirilecek bir davranış için "Bir meyve, bir tatlı veyahut alelıtlak zevk-i cismaniyi temin eden bir şey verilmemelidir”.

Öğrenciler nazarında değeri düşmemesi için mükâfat çok s1k verilmemeli, hak etmeyen öğrenciye mükâfat vermekten kaçınılmalıdır (Sami, 1328, s. 206). 
Sami Bey: "Mükâfat şahsi olmalıdır, izafi olmamalıdır." demektedir. Yani bir çocuk bir hafta veya on beş gün önceki performansına göre değerlendirilmeli, ciddi bir ilerleme kayıt etmiş ise ödüllendirilmeli, başka öğrencilere göre değerlendirilmemelidir.

Muallim mükâfatın öğrenciler arasında bir eğitim aracı olmaktan çıktı̆̆ına, öğrenciler arasında birbirine kin duyma veya fesada sebep olduğuna şahit olursa bu usulü geçici olarak hatta tamamen ortadan kaldırabilir (Sami, 1328, s. 207).

Sami Bey'in eğitimcilere tavsiye ettiği mükâfatlar şunlardı:

1. Metih ve sena: Mükâfatların en basiti budur. Çok sıklıkla kullanılmıyorsa tesirli olur. Öğretmen, öğrenciyi diğer çocukların olduğu ortamda ve yüksek sesle övmelidir (Sami, 1328, s. 208).

2. Aferin varakalarıyla tahsinnameler: "İlm-i terbiyede en küçük vasıta bile, yolunda isti'mal olunmak şartıyla faidelidir ki işte aferin varakaları da bu kabildendir". Aferin varakaları, çocukların bir hafta zarfında derse olan gayretlerinden ve güzel hâl ve hareketlerinden aldığı numaraların toplamı kimin fazla ise öğretmen adı geçen varakayı ona verir. Öğretmen, aferin varakasını, çok fazla dağıtmamalı, öğrenciler yanında değerinin azalmamasına dikkat etmelidir. Öğretmen dağıttığı aferin varakalarını düzenli olarak bir deftere kaydetmelidir.

Öğretmenin verebileceği diğer bir ödül belgesi ise tahsinamelerdir ki bunların bir tanesi, yirmi, yirmi beş veya otuz aferin varakasına bedeldir (Sami, 1328, s. 209).

3. Levha-i Şeref: Her ay sonunda gelecek ay sonuna kadar kalmak üzere okulun göze çarpan bir yerine o ay zarfında tahsinname alan ve okul kurallarına uyan öğrencilerin isimleri yazılı levha-i şeref ismi verilen bir levha asılır.

4. Kitap ve Hediyeler: Mükâfat için kitap verilebileceği gibi, kurşun kalem, hokka $v b$. ders araç ve gereçleri de verilebilir. Yalnız bu hediyelerin çok kıymetli olmamasına ve sık sık verilmemesine dikkat edilmelidir. Kitap ve hediyeler daha önceden öğretmenin belirlediği ki bu dört ile altı arasında değişebilir, tahsinnamelere verilir. Kitap ve hediyeler senede en az bir kere verilmeli; ama imkân dâhilinde ise altı ay veya üç ayda bir de verilmelidir (Sami, 1328, s. 210).

Sabri Cemil talebelerin okuldaki bütün davranışlarının karşılığını, olumlu veya olumsuz görmeleri gerektiği fikrindeydi. Öğrenciler iyi bir şey yaptıkları zaman ödüllendirilmelidirler. Aksi takdirde "Gözleri yıldırılmış olur” (Cemil,1326, s. 112). 
En iyi mükâfatlar maddi olmayan mükâfatlardır. Bu cümleden olarak öğrenci hakkında sitayişle bahsetme çok uygun bir mükâfat çeşididir (Cemil,1326, s. 115).

Eğitimde mükâfatı önemseyen Osmanlının önemli yenilikçi pedagoglarından Selim Sabit (Altın, 2013a, s. 199-214), öğretmenlerin öğrencileri şu dereceler ile ödüllendirmelerini istemekteydi:

Öncelikle kırmızı renkli "Nişane-i Aferin” kâğıdı ile ikinci olarak yeşil renkli “Nişane-i Tahsin" kâğıdı ile son olarak da sarı renkli "Nişane-i imtiyaz" kâğıdı ile ödüllendirilmelidirler (Şanal, 2003, s. 158; Sabit, 1299, s. 32; Akyüz, 2001, s. 189). Bunun yanında öğrenciler, sınıf birincisi ilan edilerek, öğrencilerin önünde övülerek, ismi onur listesine yazılarak da mükâfatlandırılabilirler (Binbaşığlu, 1995, s. 30).

\section{Pedagogların Ceza ile İlgili Görüşleri}

Selim Sabit Efendi, mümkün olduğu kadar eğitimcilerin cezadan uzak durmalarını istemekteydi. Ceza verilmesi gerekiyorsa kızgınlığ 1 geçtikten sonra ceza vermeliydi. Ayrıca ceza ile kabahat arasında uçurum olmamalıydı. Her şeye rağmen öğretmenlerin öğrencileri cezalandırma zorunda kaldıklarında takip edecekleri yedi öneri sunmaktaydı:

Öncelikle talebe, bir kabahat işlediğinde önce ona bir babanın evladına yaptı̆̆g gibi tembihte bulunmalıdır. İkinci olarak; uygun bir lisanla uyarmalıdır. Üçüncü olarak; bulunduğu şubede en aşağı yere oturtmalıdır. Dördüncü olarak; şubesinden ayırarak derse çalıştırmalıdır. Beşinci olarak; ayakta bekletmelidir. Altıncı olarak; yemek ve teneffüs zamanlarında sınıfta yalnız bırakmalıdır. Son olarak da velisi ile görüşerek birkaç gün okuldan uzaklaştırmalıdır (Sabit, 1299, s. 3; Bilim, 2002, s. 216).

Eğitimde mücazatı (ceza) da önemli bir araç olarak kabul eden Sabri Cemil'in kanaatine göre öğrenciye verilecek en iyi ceza yöntemlerinden biri, onu sevdiği şeylerden mahrum etmekti (Cemil, 1326, s. 117). Tembih ve tekdir de mücazat olarak kullanılabilir. Fakat eğitimci yerli yersiz bunları kullanacak olursa, örneğin sık sık tekdir ederse bir müddet sonra öğrenci üzerinde hiçbir etkisi kalmaz (Cemil, 1326, s. 118).

Sabri Cemil, öğrencilere yazı ve ezber cezasını da uygun bulmaktaydı. Okuldan kaçan bir çocuğa "Yalancının evi yanmış kimse inanmamış, ben de bir daha yalan söylemeyeceğim." veya "Mektepten kaçanlar haylaz olurlar, cahil kalırlar. Mektebe her gün seve seve geleceğim.” cümleleri ceza olarak yazdırılırsa etkili olur (Cemil,1326, s. 120). 
Muallimler ceza verirken şu noktalara dikkat etmelidir:

1. Ceza işlenen suç ile orantılı olmalıdır.

2. Ceza çok sık verilmemelidir.

3. Cezalar tedricen verilmeli, önce hafif cezalardan başlanmalıdır.

4. Verilen ceza suç ile irtibatlı olmalıdır. Kavga eden çocuğu oyun arkadaşlarından mahrum etmek gibi (Cemil,1326, s. 121).

Eğitimde dayak ve şiddete kesinlikle karşı çıkan Abdullah Vehbi Bey, eğitimde ceza ve şiddet yerine tembih ve güzel muamelenin tercih edilmesi taraftarıydı. Zira öğrencilere ikincisi ile yaklaşmak her zaman daha çabuk sonuca götürebilir (Vehbi,1315, s. 6).

Musa Kâzım Bey, eğitimcilerin ceza verme konusuna ödülden daha fazla titiz davranmalarını istemekteydi. Nasıl ki mahkemelerde suçlunun cezası için delil aranıyorsa, okulda da suçluların cezası delil ile sabit olmadığı sürece öğrenciye ceza verilmemelidir. Aslında öğrenciye ceza vermek son çare olarak başvurulacak bir iş olmalıdır. Öğretmen bunun için öğrenciyle güvene dayalı bir ilişki geliştirmeli, kendini öğrenciye sevdirmelidir. "Şakirdan ile muallim beyninde hüsn-i itimad hâsll olunca mücazata müstahak ve kabahiye nadiren tesadüf olunur." (Kâzım, 1310, s. 21).

Musa Kâzım kanaatince her şeye rağmen öğrenciye ceza verilmesi kaçınılmaz hâle gelirse, öğretmen, daha önce hak etmiş olduğu mükâfatın verilmemesi, oynanan oyunlardan mahrum edilmesi, okul paydosunda yarım saat okul mahzeninde tutulma, teneffüslerde sinıfta yalnız olarak ders çalıştırılması, bir hafta okuldan uzaklaştırma ve nihayet okuldan kaydının silinmesi gibi cezalara başvurabilir. Ancak eğitimci talebenin öğrenim hayatını olumsuz etkileyecek cezalardan kaçınılmalı; fakat onun gücüne gidecek cezaları vermelidir. Misal öğrenciler geometri dersine çalışmıyor ise akşam tatiline geç çıkartılabilir yahut öğrenciye daha zor geliyor ise bunun yerine geometri ile ilgili problemler yazdırılabilir (Kâzım, 1310, s. 22).

Mustafa Satı'nın fikrine göre eğitim işini icra edenlerin öğrencilerin terbiyesinde başarı sağlamaları için onların seciyeleri hakkında bilgi sahibi olmaya mecburdurlar. Çünkü öğretmenin öğrencilere verdiği herhangi bir emir "maraz" tabiatlı bir öğrencide farkl1, mülayim tabiatlı bir öğrencide farklı tesirler bırakır (Satı,1325, s. 332). Mücazat (Ceza) ve mükâfat (Ödül) konusu da bu çerçevede değerlendirilebilir. Bazı öğrencileri birincisi, bazılarını ikincisi daha çok etkiler. 
Bir hekim nasıl hastasının rahatsızlığını teşhis edip ona göre tedbir alıyorsa, öğretmen de öğrencisinin seciyesini bilip ona göre gerekli tedbiri almalıdır (Satı,1325, s. 333).

Eğitimde ceza ve ödül konularına en fazla mesai harcayan pedagoglardan biri de Süleyman Paşazade Sami Bey idi. Ona göre çocukların muallim hakkındaki sevgileri ona hoş görünememek korkusunu ortaya çıkarır. Bu korku ile "Mücazat korkusu"nu birbirine karıştırmamak lazımdır. İkincisi faydasız ve çirkin bir şeydir. Ancak bazı çocuklar vardır ki huysuz ve terbiyesizdirler. Bunları muallime hoş görünmek gibi bir kaygıları yoktur. Bu gibilere küçük mükâfatlarda fayda etmez tek çare usulüne uygun ceza yöntemine başvurmaktır. Söz konusu öğrencilerle başa çıkmak için bir öğretmene lazım olan şey metanettir (Sami, 1328, s. 200).

Sami Bey, mücazat-1 cismaniyenin mutlaka okuldan kaldırılması gerektiğine inanmaktaydı bunun gerekçesini ise şu şekilde açıklamaktaydı:

Mücazat-1 Cismaniye korkusuyla hareket eden bir çocuk, görünüşte yaptığı şeyler ne kadar kusursuz olursa olsun hatta mükemmel derecede ortaya bir şeyler koymuş olsun, gerçekte hiçbir olumlu şey yapması mümkün değildir. Onu kötülükten alıkoyan korkusudur yoksa nefsi 1slah olmamıştır ve uygun ortam bulduğunda kötülük yapmaktan vazgeçmez. Söz konusu cezanın aile içinde uygulanmasına ise, "Pek o kadar mahzuru olmadı̆̆g" yönünde fikir beyan etmekte idi (Sami, 1328, s. 203). Sami Bey, okulda aç bırakmak, ayakta beklemek gibi cezalara da karşı çıkmaktaydı (Sami, 1328, s. 211).

Sami Bey’in düşüncesine göre, bazı “Büsbütün bozuk tabiatlı” öğrenciler vardır ki ödül ne olursa olsun onların düzelmesi mümkün olmaz. Bu tür öğrenciler için eğitimcinin cezaya başvurmaktan başka çaresi yoktur. Ceza öğrencileri ders çalışmaya, dik başl1ları yola getirmeye ve uygunsuz davranışların kötü neticelerini göstermeye hizmet etmelidir. Ayrıca muallim, öğrenciye ceza verirken okulun kuralları dışına çıkmamalı, daha önce konulan kural neyi gerektiriyorsa o cezayı vermelidir. Ceza verir iken amacın "Tecziye değil, tadil ve ıslah" olduğu unutulmamalıdır (Sami, 1328, s. 205).

Sami Bey, eğitimcilerin öğrencilere bedeni acı veren ceza vermesine karşı çıkmakta idi. Eğitimci ceza olarak kırgınlığını, hoşnutsuzluğunu belli eden davranışlar içerisine girmeliydi. Sami Bey, ceza ile öğrenciyi uyarı ve tembih etmeyi amaçlamaktaydı (Sami, 1328, s. 211). Ona göre muallim, ceza konusunda şunlara dikkat etmeliydi: 
1. Bir okulda ceza nadir olarak verilmelidir. Aksi takdirde çocuklar cezaya alışırlar ve cezaya ehemmiyet vermemeye başlarlar. Ceza sık verildiği takdirde öğrenciler bunu bir oyun eğlence hâline getirebilirler.

Cezaların nadir verilmesi demek, öğrencilerin bazı kusurlarını, kötü hareketlerini görmeme anlamına gelmemelidir. Bilakis öğretmen, öğrencilerin hiçbir uygunsuz fiillerine kayıtsız kalmamalıdır. Fakat arzu olunan cezai durumların az olması ve hatta ortadan kalkmasıdır. Burada görev yine öğretmene düşmektedir. Öğretmen, öğrenciye okulu ve tahsili sevdirmelidir. "Bir mektepte cezaların çokluğu sırf muallimin kusurudur. Muallim talebeyi ele alamamış, onları zabt ve idare etmesini bilememiş demektir" (Sami, 1328, s. 212). Öğretmen, öğrenciyi defalarca ikaz ettikten sonra kendisini düzeltmezse ceza vermelidir (Sami, 1328, s. 213).

2. Cezalar Yararlı Olmalıdır. "Cezalar müfid olmalıdır, yani vaki' olan hatayı tashih itmekle beraber, çocukların fikir ve kalbini tadil ve islah ve talim ve terbiyelerini ikmal ve itmam edecek şeyler olmalıdır". Mesela, birbiriyle anlam bağı olmayan alakasız kelimeleri, manasız cümleleri, sonu gelmeyen şiirleri kopya ettirmek gibi cezalar faydasız ve gülünçtür (Sami, 1328, s. 213).

Öğrenciye, ceza olarak yazı kopya ettirilecekse bu yazının faydalı bilgiler içermesi, öğrencinin yazdıklarından bir şeyler öğrenmesi şarttır (Sami, 1328, s. 214).

3. Ceza makul olmalıdır. Akla mantığa uygun olmalı, çocuğun yaşı ve gücüne uygun olmalıdır. Ceza için verilen zaman ile cezanın kendisi mütenasip olmalıdır. Ayrıca çocuğun ruh ve beden sağlığına zarar verecek cezalardan kaçınılmalıdır (Sami, 1328, s. 214).

4. Ceza, hiddet edilmeyerek, hilm ile tatbik edilmelidir. Bundan olayın üstünden zaman geçmesi ve öğretmenin yatışması anlaşılmamalıdır. Bilakis cezayı gerektirecek suçun üzerinden zaman geçmesi, cezanın geciktirilmesi cezanın etkisini ortadan kaldırır. Bununla birlikte öğretmen sakin olmalı soğukkanlılı̆̆ını muhafaza etmelidir (Sami, 1328, s. 215).

5. Cezalar kati olmalıdır. Muallim verdiği bir cezadan talebenin tepkisi üzerine geri dönmemeli, değiştirmemeli ve ilk verdiği cezayı icra etmelidir. Bu sebeple öğretmen arkasında duracağı bir cezayı seçmelidir. Öğrenciler cezaya itiraz ettiği zaman öğretmen sükûnetini muhafaza etmeli, soğukkanlılığını korumalı, şiddete yönelmemeli ama nihayet kendi sözünü dinletmelidir (Sami, 1328, s. 216). 
Sami Bey, eğitimcilerin verebilecekleri cezalar hakkında görüşlerini açıkladıktan sonra öğretmenlerin öğrencilere verebilecekleri cezaları şu şekilde sıralamaktaydı:

1. İhtar ve tevbih: Çocukluktan kaynaklanan bazı hafif kusurların karşılığı olan bir ceza türüdür. Özel olarak bir öğrenciyi olduğu gibi bir sınıfı uyarmakta mümkündür. Yalnız başına bir öğrenciyi uyarmak daha faydalıdır. Öğretmen ihtar ve tevbih olarak öğrencinin sınıf içerisindeki yerini geçici olarak değiştirebilir (Sami, 1328, s. 217).

2. Aferin istirdâdı: Çocukların daha önce almış oldukları aferin ve tahsin varakalarını geri almak anlamında bir cezadır. Sami Bey, hem maddi hem manevi bir zarar olarak değerlendirdiği bu cezayı, öğretmenlerin öğrenciler ağır bir suç işledikleri zaman vermelerini istemekteydi (Sami, 1328, s. 218).

3. Bir ismi levha-i şereften silmek: Bir ay önce ismi şeref levhasına yazılan öğrencinin ikinci ay zarfında oldukça ağır bir hata yapması durumunda ismi şeref levhasından çıkarılır. Öğrenci, sonraki aylarda kendisini düzeltir, derslerinde gayret gösterirse ismi şeref levhasına tekrar yazılır (Sami, 1328, s. 218).

4. Yazı cezasıyla beraber tevkif: Öğrenciyi ders zamanı dışında okulda veya sınıfta alıkoymak anlamına gelen bu cezaya çarptırılan öğrenci, cezasını çekerken boş durmamalı, kendisine verilen ödevi yapmamış veya çok kötü yapmışsa tekrar yapması sağlanmalıdır. Öğretmen, söz konusu öğrenciye bir matematik problemi çözdürebilir; yahut güzel bir yazıyı kopya ettirebilir (Sami, 1328, s. 218).

5. Tard: Diğer cezalardan uslanmayan çocuğun okuldan geçici olarak uzaklaşmasının diğer öğrencilere faydası olacağı kanaati öğretmende hasıl oluyorsa bu ceza icra edilmelidir. Bir öğrencinin okuldan kesin tardı ancak öğrencinin ebeveynine haber verilerek Maarif Nezaretince yapılabileceğinden, öğretmen öğrenciyi sadece geçici olarak okuldan uzaklaştırabilir ki umumiyetle bu ceza çocuğun düzelmesine kâfi olur (Sami, 1328, s. 219).

\section{Sonuç}

Disiplin, ödül ve ceza kavramlarının eğitimdeki yeri her zaman önemsenmiş ve tartışılagelmiştir. Esasen söz konusu kavramları da kapsayan, modern anlamda pedagoji tartışmalarına Osmanlı'da Tanzimat döneminde rastlanmaya başlandı. II. Abdülhamid ve II. Meşrutiyet devrinde de pedagoglar konuyu tartışmaya devam ettiler. 
Selim Sabit, söz konusu kavramları Tanzimat döneminde eğitimcilerin gündemine getiren isim oldu. II. Abdülhamid devrinde Musa Kâzım, Melekzade Fuad, Abdullah Vehbi gibi isimler disiplin, ödül ve ceza kavramlarını eserlerinde tartıştılar. II. Meşrutiyet devrinde eğitim ile ilgili kalem oynatanlar da konuya sessiz kalmadılar. Sabri Cemil, Halide Edip, Süleyman Paşazade Sami eserlerinde disiplin, ödül ve cezanın eğitimdeki yeri hakkında dönemin muallim ve muallimelerinin bilgi sahibi olmasını sağladılar. Her üç devirde konuyu ele alan isimler aynı zamanda okullarda ders de vermekteydiler. Yani saha hakkında bilgi sahibi ve konuyla ilgili pratiği, tecrübesi olan kimseler idiler.

Adı geçen eğitimcilerin konuya yaklaşımları, günümüz modern eğitim bilimiyle büyük oranda örtüşmektedir. Zamanımızda konunun uzmanları da disiplini eğitim-öğretimin olmazsa olmaz öğelerinden saymaktadırlar. Aynı şekilde ödül ve ceza konusu da hâlâ eğitimcilerin meşgul olduğu kavramlardır. Osmanlı pedagogları disiplin, ceza ve ödül meselelerinde çağdaş halefleriyle birçok konuda aynı fikirde idiler. Bununla ilgili bazı örnekler vermek gerekirse:

Ceza ve ödülün çocuğun yaşına uygun olması fikrindeydiler. Cezanın genç bireyin izzet-i nefsini kırmaması, ödülün de şımartmamasını önemsemekteydiler. Faydası olmayan ceza ve ödülü men etmekteydiler. Ödül ve cezanın çok sık başvurulan eğitim-öğretim yöntemi olmasına karşıydılar. Ödül ve cezanın talebenin yaptığı davranışlarla müsemma olmasını önemsemekteydiler. Öğretmenin öğrencilerin tepkileri karşısında kararlı olmasını; fakat soğukkanlılığını muhafaza ederek şiddetten kaçınmasını salık vermekteydiler.

\section{Kaynaklar}

Abdullah, V. ( 1315). Usûl-i ibtidaî yahut muallimlere rehnüma. Trabzon.

Akyüz, Y. (2001). Türk eğitim tarihi. İstanbul: Alfa Yayınc1lık.

Altın, H. (2009). II. Abdülhamid ve II. Meşrutiyet devirlerinde öğretmen yetiştirme meselesi. Yayınlanmamış Doktora Tezi, Ankara: Ankara Üniversitesi Sosyal Bilimler Enstitüsü.

Altın, H. (2013). II. Meşrutiyet devri pedagoglarından Sabri Cemil ve Amelî Fenn-i Tedris’i. Turkish Studies, 8(2), 19-35.

Altın, H. (2013). Kilisli Rıfat'ın hocalarından Selim Sabit Efendi ve meslektaşlarına öğütleri. I. Uluslararası Muallim Rıfat Kilis ve Çevresi Sempozyumu. 16-17 Mayıs, 199-214.

Berkes, N. (2002). Türkiye'de çağdaşlaşma (Yayına Hazırlayan: Ahmet Kuyaş). İstanbul: YKY. 
Bilim, C. (2002). Türkiye’de çağdaş eğitim tarihi. Eskişehir: Anadolu Üniversitesi Yayınları.

Binbaşıŏlu, C. (1995). Türkiye’de eğitim bilimleri tarihi. Ankara: MEB.

Cemil, S. (1326). Amel-i fenn-i tedris. Üsküp: Kosova Matbaas1.

Fuad, M. (1315). Usûl-i tedris ve tederrüs. Dersaadet: Matbaa-yı Osmaniye.

Gültekin, F. (2013). Ceza korkusundan ödül bağımlılığına eğitimde ödül ceza dengesi. Bursa: Aile Akademisi

Halide Edip (1327). Talim ve terbiye. İstanbul.

Kafadar, O. (1997). Türk aydınının Sâtı Bey hakkında kimi yanılgıları üzerine düşünceler. Türkiye Günlüğ̈̈, 46.

Kardaş, R. (1978). Milli eğitimimizde öğretmen yetiştirme davası ve tuba ağacı nazariyesi. Türk Kültürü, 191-194.

Kâzım, M. (1310). Rehber-i tedris ve terbiye. İstanbul.

Mahmud Cevad İbnü'ş-Şeyh Nafi. (2002) Maârif-i Umumîye Nezareti Tarihçe-i Teşkilât ve icrââtı. Ankara: MEB.

Sabit, S. (1299). Rehnümâ-yı muallimîn. İstanbul.

Salname-i maarif-i umumîye (1317).

Sat1, M. (1325). Fenn-i terbiye. İstanbul: İbrahim Hilmi Matbaası.

Süleyman Paşazade Sami (1328). İlm-İ terbiye-i etfal. İstanbul: İkdam Matbaası.

Şanal, M. (2003). Selim sabit efendi’nin öğretim yöntemleri ile ödül ve ceza vermeye ilişkin görüşleri üzerine genel bir değerlendirme. Millî Ĕ̆itim, 158. 